\title{
THE TYPOLOGY OF THE HISTORICAL TIMBER BRIDGES OF TURKEY
}

\author{
SÜHEYLA YILMAZ HALIDE SERT \& NURDAN APAYDIN \\ Historical Bridges Division, Department of Structures, General Directorate of Highways, Ankara, Turkey.
}

\begin{abstract}
Timber was probably the first material used by humans to construct a bridge structure since Neolithic era. The oldest man-made bridges were probably done by laying tree trunks across streams in girder fashion. Later, many timber bridges were built all over the world, using many variants of beams, cantilevers, trusses and arches. In Turkey, the Hittite Bridge in Ambarlıkaya near Hattuşa, the capital city of the Hittite Empire, today in Çorum Province, is known as the oldest bridge constructed with wooden beams laid across Ambarlikaya gorge. In Turkey, historical timber bridges belonging to ancient times could not survive till now while only a few belonging to the 19th century are still standing and reflect the materials and construction technologies of the past. Those bridges, therefore, are very valuable and deserve to be discovered in terms of their technical specifications. The present study is an effort to classify the historical timber bridges in Turkey that have survived up until today. To do that, the study has started with literature survey about the historical development and classification of timber bridges throughout the history in the world. By using that knowledge, the historical timber bridges in Turkey were classified in groups depending on their construction technologies. Discovery of the visible and invisible technical features of historical timber bridges has vital importance for transferring that knowledge to conservation practitioners for repairs and maintenance of these bridges. This research is, in fact, a useful and effective attempt to transfer that knowledge achieved in the past to young generations.

Keywords: conservation, historical timber bridges, preservation, typology.
\end{abstract}

\section{INTRODUCTION}

Anatolia which has witnessed the development of various civilizations for centuries was covered with road network to meet the communicational, militaristic and commercial requirements of the societies. Within this process, as part of the transportation system the bridges have turned out to be the supplementary elements of the cultural history as beneficial structures serving for commercial, economic, militaristic, social and cultural purposes.

In addition to constructing new roads and bridges, improving the existing historical bridges through maintenance and repair is also among the primary duties of the General Directorate of Highways. According to the Division of Historical Bridges' Inventory (as of December 2016), it has been observed that there exists a total of 1948 each bridges in our country the majority of which is located on first-degree seismic zone, dating back to Hittite (1), Urartian (1), Roman (142), East Roman (26), Seljuk (160), Ottoman (1509) and Early Republican (105) periods with 316 bridges dating back to Ottoman Period, the majority of which is located in Bosnia and Herzegovina. 1948 bridges are classified according to their construction technique as follows: stone (1834), wooden (38), iron (34) and reinforced concrete (42) $[1,2]$.

Timber was probably the first material used by humans to construct a bridge structure since Neolithic era. The oldest man-made bridges were probably done by laying tree trunks across streams in girder fashion. Later, many timber bridges were built all over the world, using many variants of beams, cantilevers, trusses and arches. 


\section{HISTORICAL DEVELOPMENT AND CLASSIFICATION \\ OF TIMBER BRIDGES IN THE WORLD}

Timber has been widely used as a construction material from the first instances of bridge building to the modern designs. There are several advantages of timber as a construction material. It has a high strength to weight ratio; it is natural, renewable and sustainable, has low embodied energy content during manufacture, and with regular surface treatments and protection, longer service life can be ensured easily. It is also ideal for the applications where aesthetics and beauty is important [3].

From the primitive ones built with tree trunks to the modern examples built with industrial timber, timber bridges have been built in several structural types like beam, cantilever, suspension bridge, arch and truss, and in hybrid forms such as trussed arches. Timber bridges are generally built for pedestrians, animals, cyclists or light vehicles; however with the technological developments they become suitable for relatively higher loads [3].

\subsection{Timber beam bridges}

The first and earliest examples of timber bridges are fallen tree trucks across a river which can be simply defined as a horizontal beam supported at each ends [4]. It is estimated that 17,000 years ago covered logs laid flat made up the first wooden bridges, but with spans limited to about 10 metres. Herodotus described structures with increased spans to cross the Euphrates or certain tributaries of the Nile 2,000-3,000 years ago. More details about a bridge completed in some 2,790 years ago are also found. Generally during antiquity, technical progress in wood structures should be credited to shipbuilding, in particular by the Egyptians, the Phoenicians, the Greeks and the Celts [5] (Fig. 1).

In ancient times, floating boats with intermediate piers were used as bridges to transit from one side to the another. Darius Bridge over the Bosphorus was constructed in 6th century BC, where 674 boats crossed an obstacle of about 1,500 metres [5] (Fig. 2).

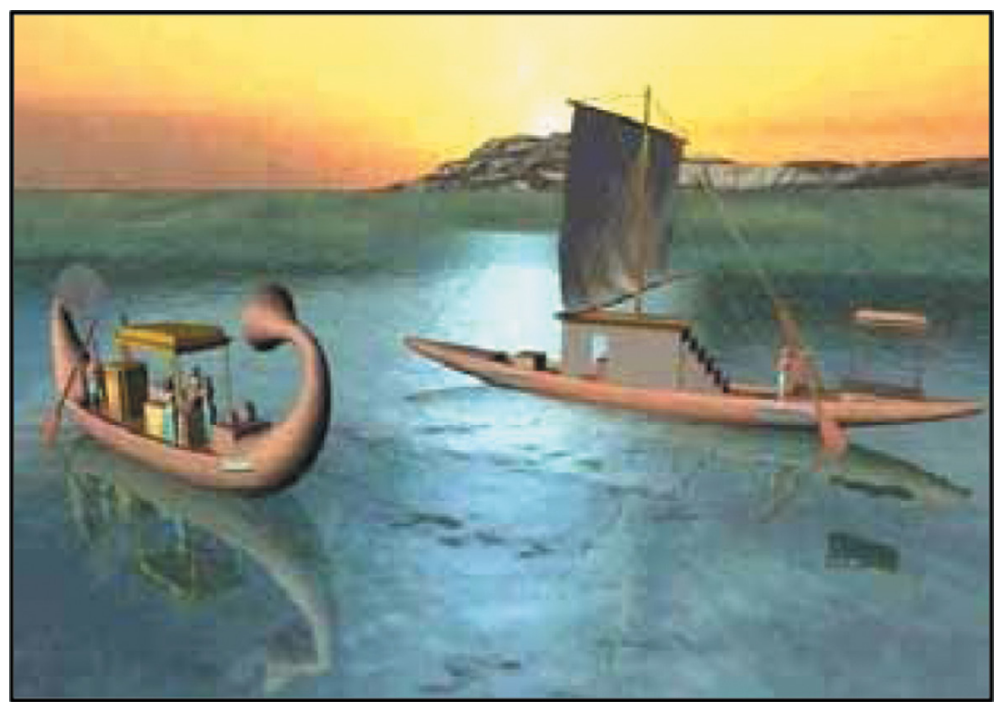

Figure 1: Egyptian ships [5]. 


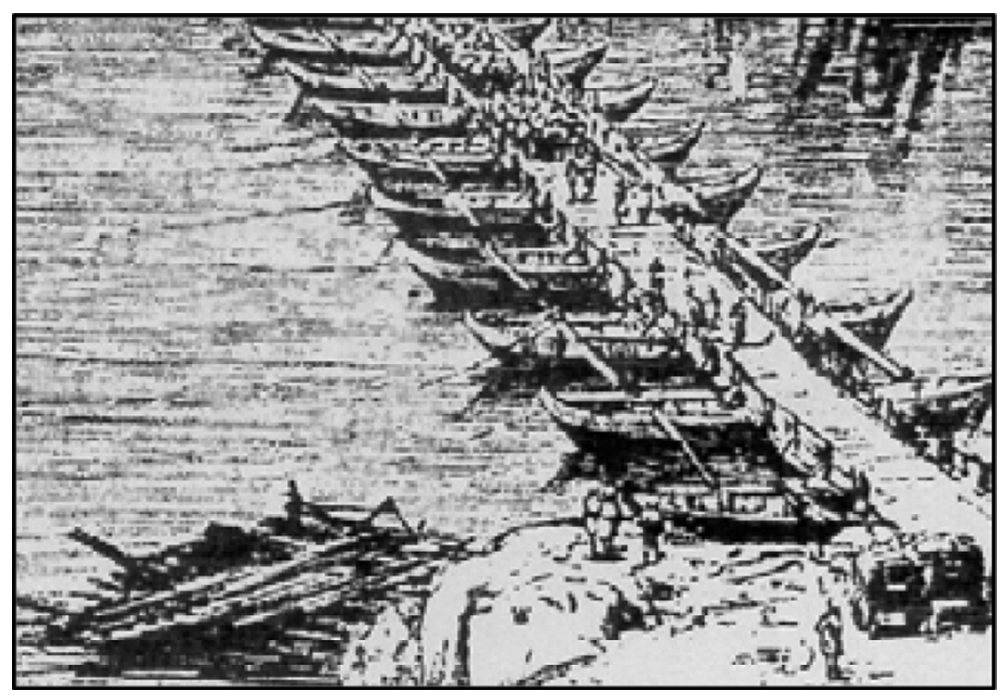

Figure 2: Bridge made of boats [5].

Later, the Romans built timber beam bridges to ease transport; in particular, one of those bridges, known as Caesar's Bridge $(55 \mathrm{BC})$, is well documented by the Italian architect Andrea Palladio (1508-1580) (Malo, 2016). The bridge was built with simple, ready-made units and was easy to erect and then to dismantle after the passage of the army. At 5-6 metres wide, it was built in only 10 days, near Neuwied, where the width of the river was 140 metres (Setra 2006) (Fig. 3).

In 16th century, Andrea Palladio, the great architect of the Renaissance, constructed timber beam bridge across the Brenta River in Bassano del Grappa (Italy) and it is described in a table of his treatise The Four Books of Architecture. The structure was repaired many times because of river floods and damages caused by war, but the one that is admired today is essentially the same bridge designed by the famous architect. The structure is a 5 span truss bridge made entirely with wooden framework [3] (Fig. 4).

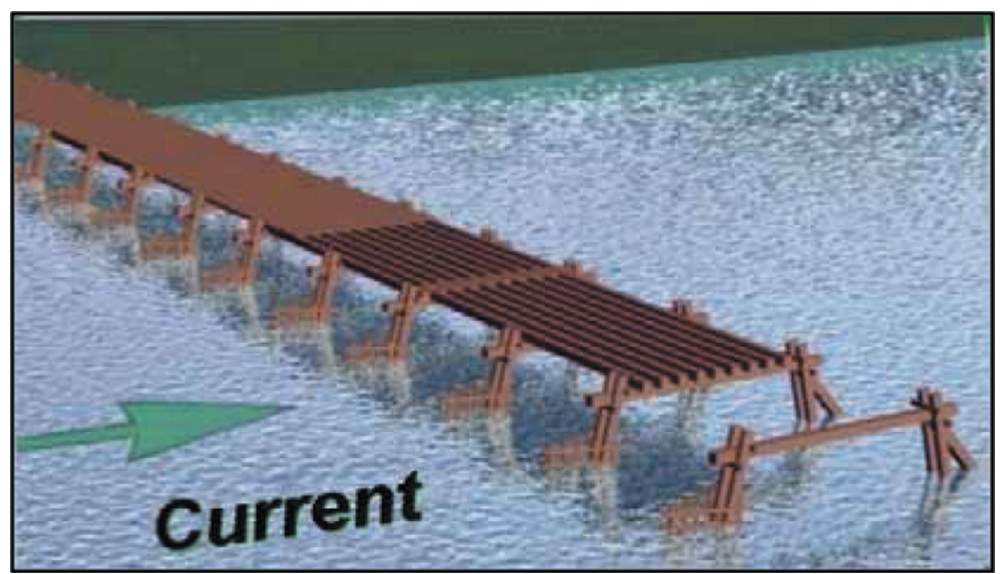

Figure 3: Caesar's Bridge [5]. 


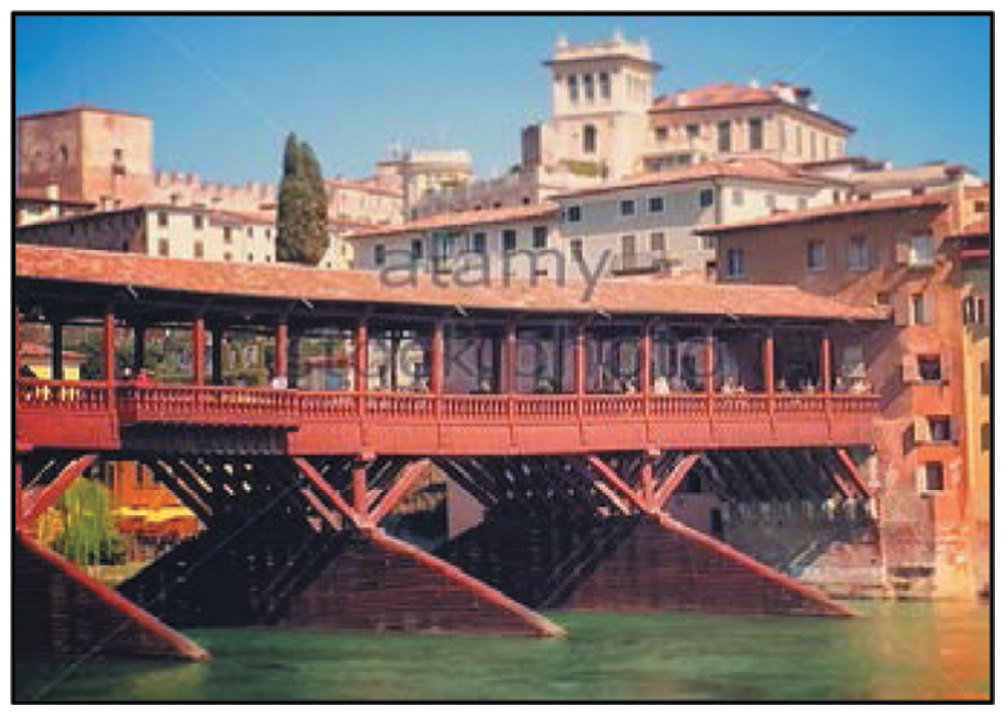

Figure 4: Palladio's Bridge [5].

\subsection{Timber cantilever bridges}

Another bridge type is the cantilever bridge which is a developed form of beam bridges to span wider distances [4]. In the absence of efficient end jointing, cantilevering is almost an instinctive method of reaching forward with the span and extending the opportunity afforded by limited length of the material [3].

Figures 5 and 6 are the examples of the cantilever timber bridges: the first one is the outside cantilevering abutment drawn by Viollet-le-Duc [5] and the second shows Bhutan's traditional cantilever timber bridges, which are aggregations of massive, interlocking wooden structures that form a single bridge [3].

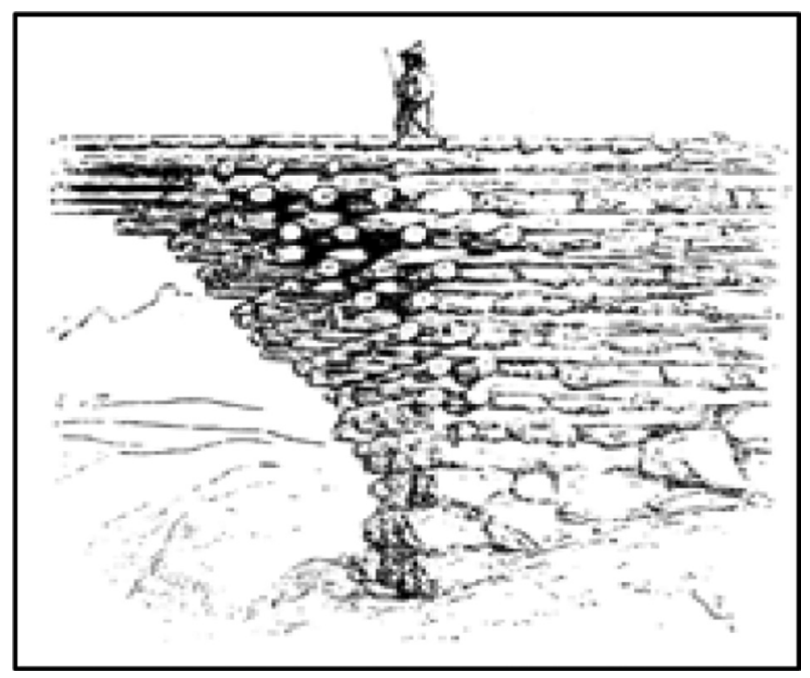

Figure 5: Outside cantilevering. 


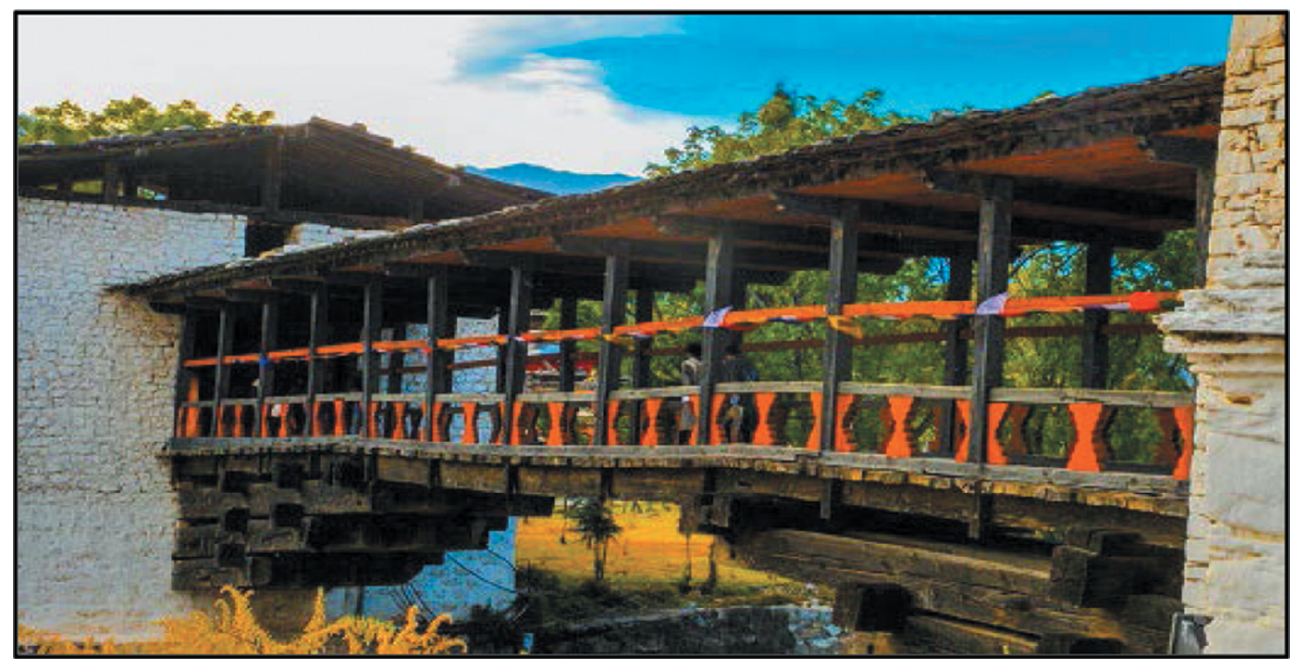

Figure 6: Cantilever timber bridge. Abutment drawn by Viollet-Le-Duc. In Bhutanesee [3] .

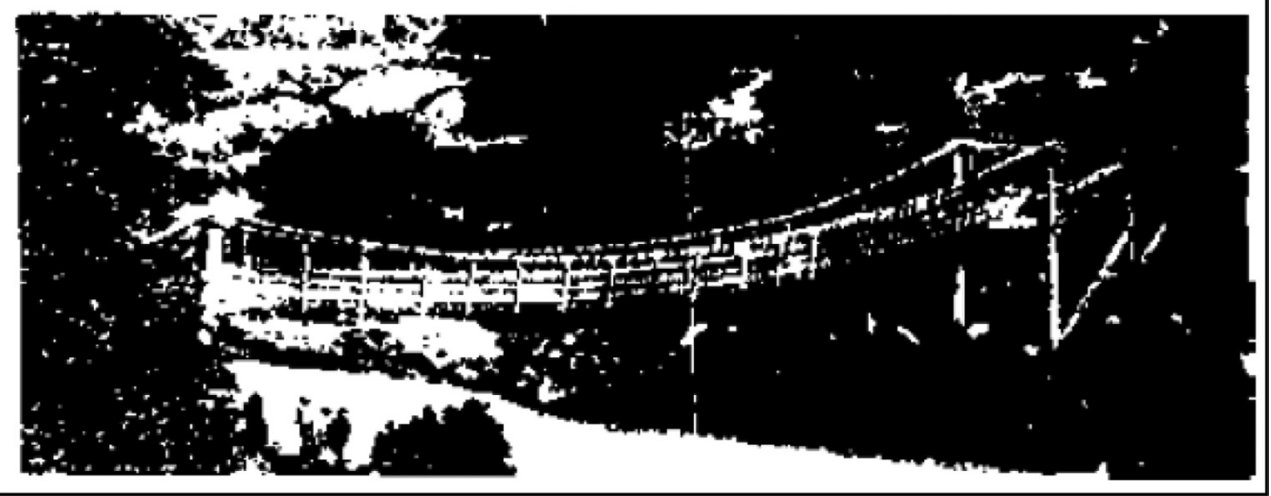

Figure 7: Early highway type of rope bridge. This example is from the İsland of Javaand which has an apparent span of approximately 100 feet (Photo courtesy: The American Society of Civil Engineers: (C) 1976) [6].

\subsection{Timber suspension bridges}

Timber Suspension Bridges also date back to the early times. Basically, a suspension bridge is formed with a rope hanging between the supports [4]. For the last two centuries the suspension bridge design has showed a great progress thanks to the developments in material science and construction technology.

Ideas for prototype suspension bridges probably came from hanging vines or stems. In subtropical parts of the world, palms with lengthy stems were used for constructing suspension bridges [6] (Fig. 7).

According to M. Goykoviç before the Mostar arched stone bridge was constructed; there had been the wooden suspension bridge with span of 35 metres and it was at the altitude of 53.20 metres above the sea level, and above the high water level (50.70 above the sea level 
on this place). His hypothetical reconstruction drawing of the pre-Ottoman bridge in Mostar is shown in Fig. 8 [7].

During the reconstruction of Ottoman Mostar Bridge between 2002 and 2004, while excavating, holes for the placement of timber beam elements and iron nails were found in the bridge site, which verified hypothesis of Goykoviç [8] (Fig. 9).

\subsection{Timber arch bridges}

The first examples of arch bridges were built with stone, which has high compressive strength and so works well in compression. In time models were built also with wood, brick, iron,

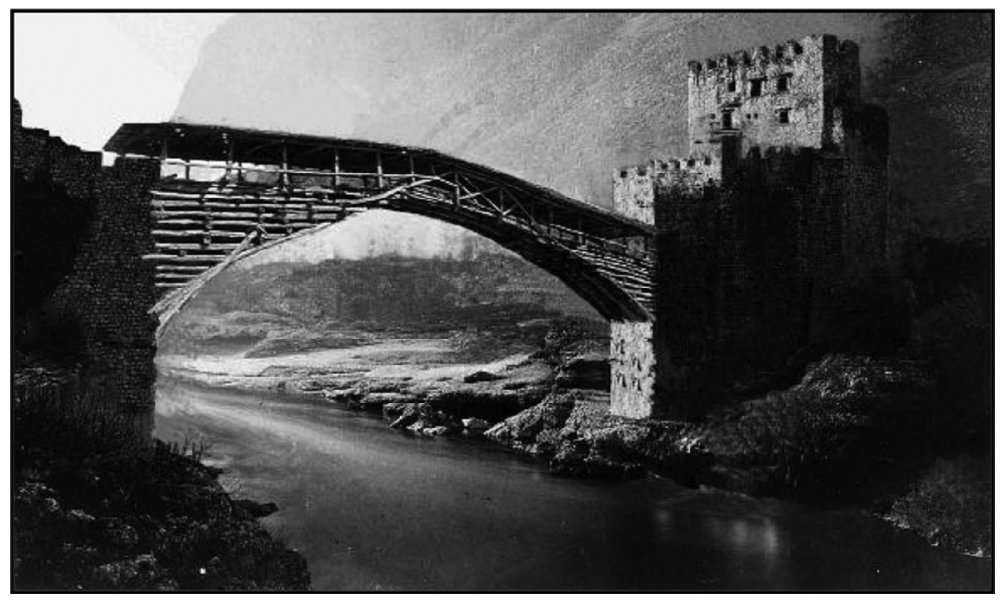

Figure 8: Hypothetical reconstruction of the investigation.

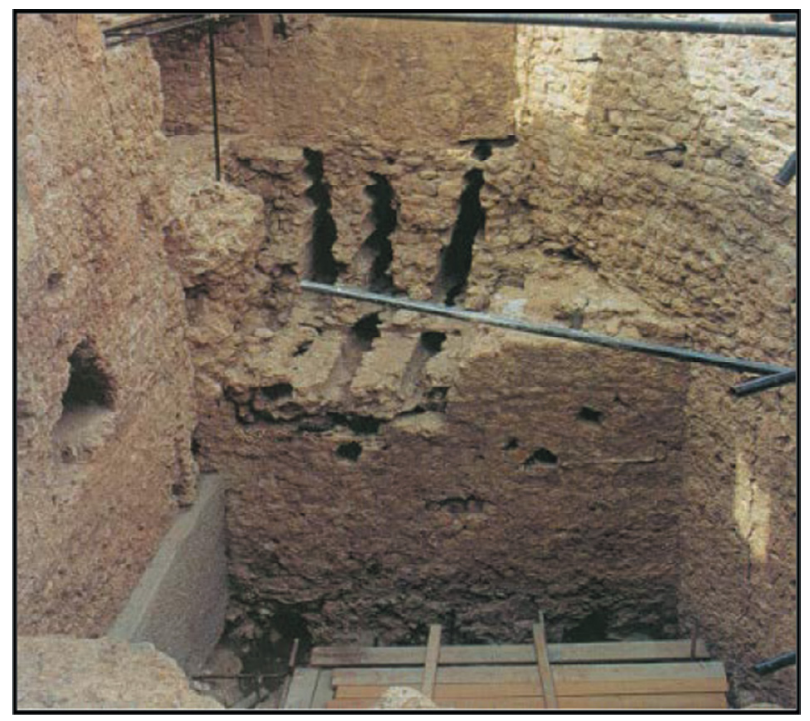

Figure 9: Archaeological pre-Ottoman bridge in Mostar [7]. Proved historical development of the bridge site [8]. 
steel and prestressed concrete [9]. Building arch bridges was the practical way for spanning large distances for many years.

During Roman Period, for the Emperor Trajan, multi-arched timber Trajan Bridge was constructed with approximately 1,200 m length. Leading to the modern day, Serbian River banks, for more than 1,000 years, is the longest arch bridge ever constructed. It carried the Via Flamina, a road that began in Northern Italy and passed the shores of the Adriatic, crossing the Alps. Trajan Bridge was depicted on Trajan Column [3] (Figs 10 and 11).

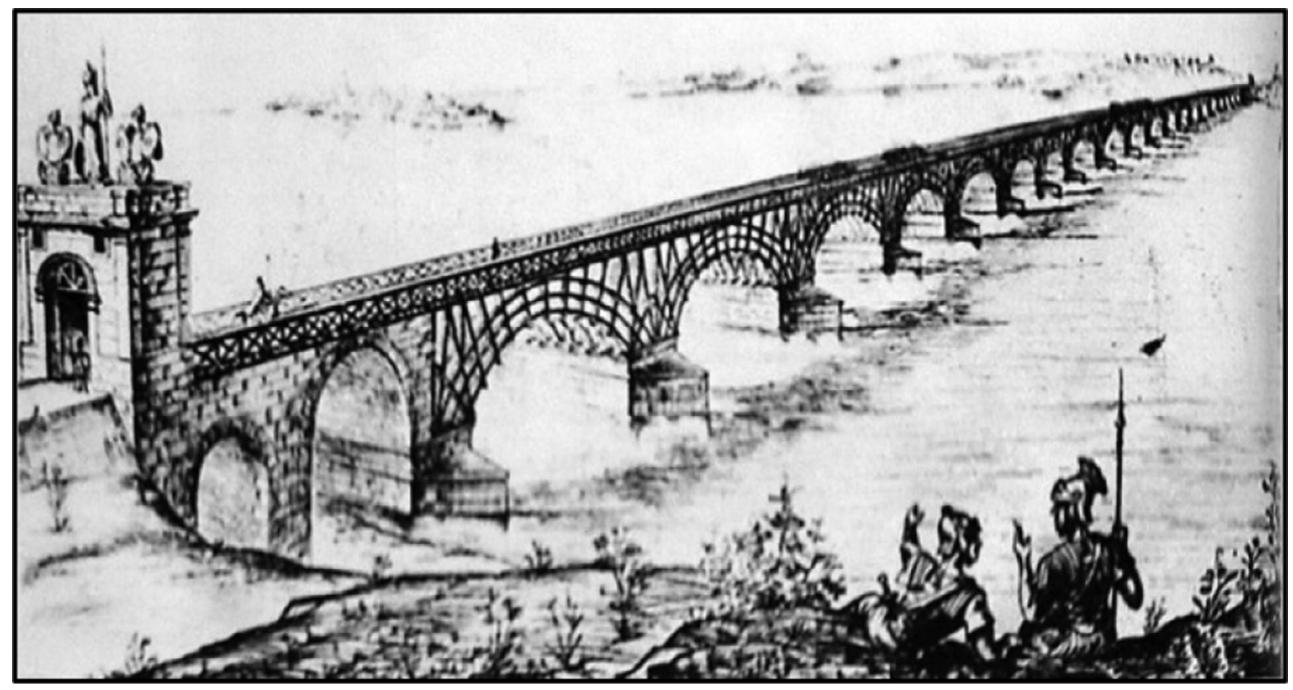

Figure 10: Reconstruction drawing of Trajan Bridge.

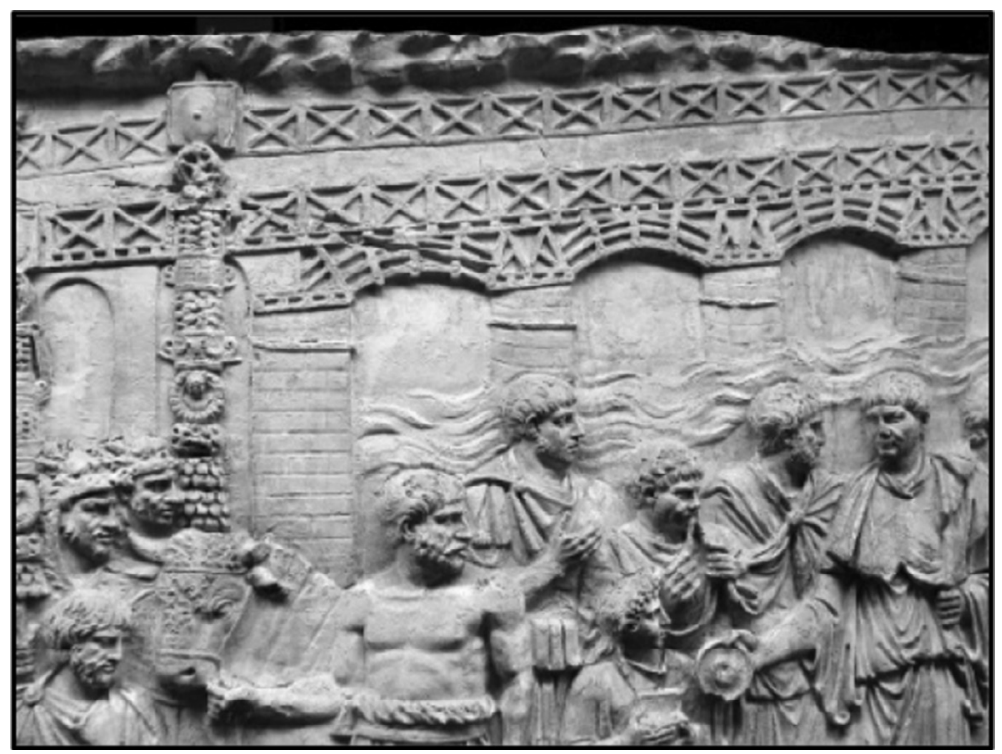

Figure 11: Trajan column and timber arch bridge depicted on it. 


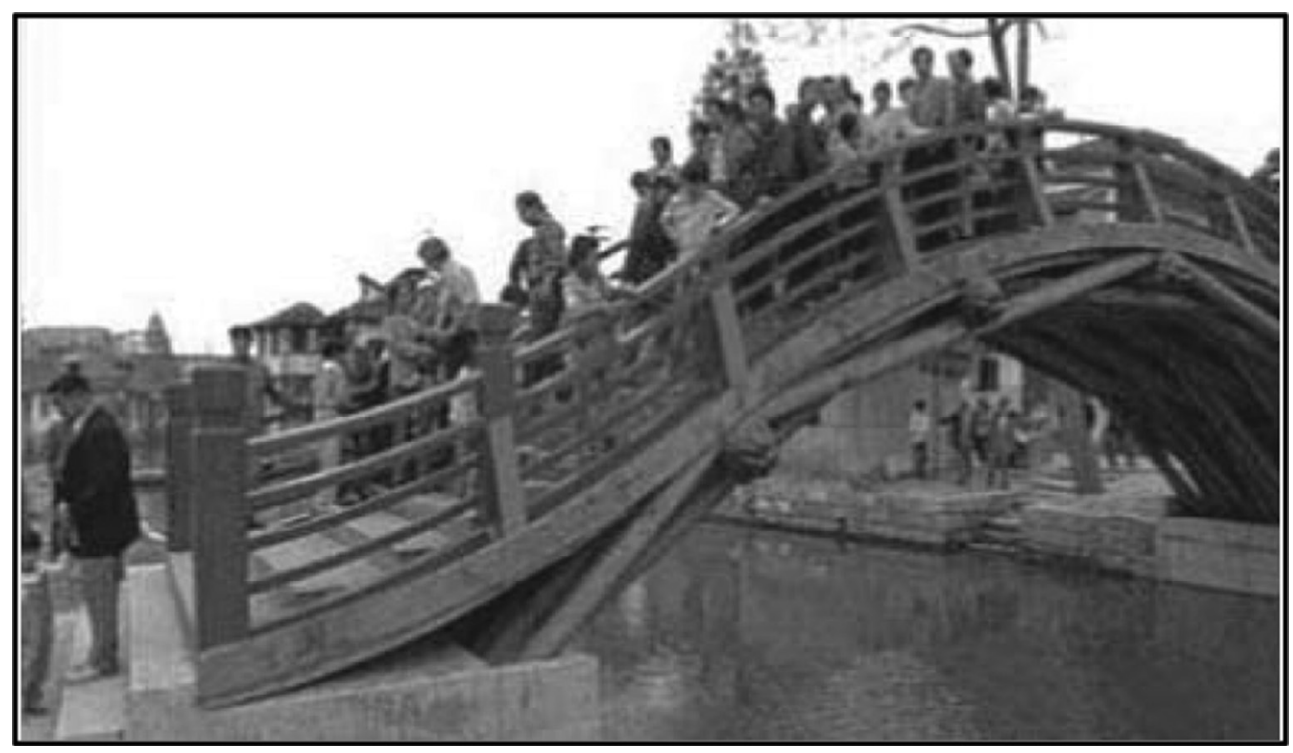

Figure 12: Side view of Chinese timber arch bridges (rainbow, woven bridge).

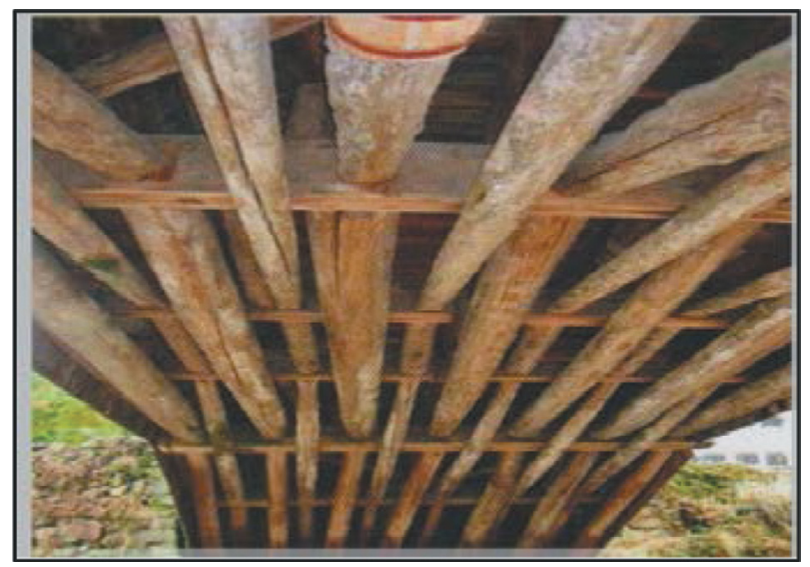

Figure 13: Introdos of main arch of Chinese timber arch bridges (rainbow, woven bridge).

China has a lot of wooden arch bridges that are with unique construction techniques and skills. The use of various techniques and materials like beams, tenons and mortises make wooden arch bridges in Fujian Province and Zhejiang Province distinctive and commendable and these are called rainbow and woven bridges which were constructed by weaving straight logs and then criss-crossing them together (Figs 12 and 13).

\subsection{Timber truss bridges}

In the 16th century, Italian architect Palladio described the truss bridge in his I Quattro Libri dell' Architettura. Truss is the structural type which consists of triangles formed with the 


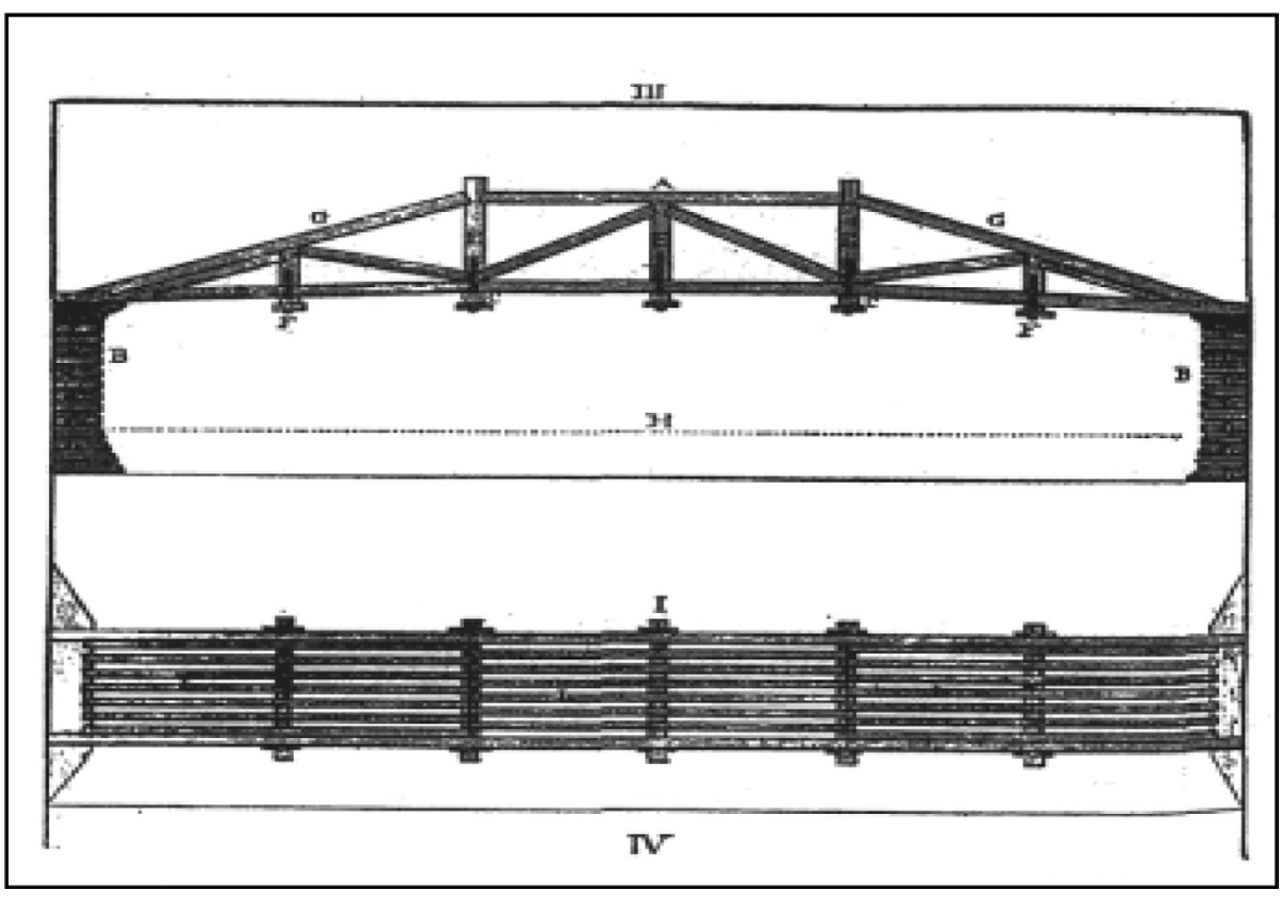

Figure 14: Palladio's truss bridge (From The Four Books of Architecture, 1736).

connected straight members. The straight members are subjected to both tension and compression forces and these forces are balanced in a truss. There are various types of trusses; however, they all have the advantage of the strength and rigidity of a triangle [10,4]. The first models of truss bridges were constructed with wood. With the Industrial Revolution, iron and steel replaced wood in the 19th century [10].

Palladio's trussed footbridges which are statically determinate show his ideas were remarkably advanced for the time 1579; he had recognized the importance of achieving clear spans and using iron straps and bolts (Fig. 14).

\section{STRUCTURAL CLASSIFICATION OF TIMBER BRIDGES IN TURKEY}

Traditionally timber was used in bridge construction; however stone is stronger and as a result able to better withstand natural conditions. Therefore, a very few bridges dating back to 150 years ago as a maximum have survived to date [1].

Although it is a well-known case that there exist 35 bridges constructed generally by the local communities in Black Sea Region, the photographs for only 25 of such bridges have been found out. Of these, 15 of them have survived to the present time [1]. The far superior properties of timber against stone are its lightness and tensile and flexural strength. Such features of timber allowed construction of overflow structures and safer passageway for larger spanning [3].

The timber bridges located in our country are mostly built on masonry piers and settled on the blocks supported by the main girder forming part of the massive flat system by overlapping the longitudinal and transverse beams on each other. The timber materials are used on the floor coverings, pillars and parapets while some of the bridges are covered 
by roofs. The trees such as pine, oak and chestnut have commonly been used in the construction of the bridges and the timber materials have been connected through clearance method using iron nails. In Turkey, timber bridges survived today were constructed using

- beam,

- cantilever,

- suspension and

- hybrid forms.

\subsection{Timber beam bridges}

The first and earliest examples of timber bridges were constructed with fallen tree trucks across a river which can be simply defined as a horizontal beam supported at each ends.

In Turkey, the Hittite Bridge in Ambarlıkaya near Hattuşa, the capital city of the Hittite Empire, today in Çorum Province, is known as the oldest bridge constructed with wooden beams laid across Ambarlıkaya gorge, as Rudolf Nauman suggested. Inside the gorge there are many cupules or holes in the wall possibly to place the beam construction to hold a wooden platform or a footway [11].

According to Nauman, the bridge was constructed to pass 8.50 metres span of the yard by stones on to the cavernous rocks in the form of stairs while the paved superstructure is passed through timber beams [11] (Fig. 15).

The second example from Turkey is Pulur which is also known as Yavuz Sultan Selim Bridge (Figs 16 and 17). It is located in Erzurum, Pulur Province, on Pulur River. It was constructed in the 15th century during the Ottoman Period with 135.35 metres length and 5.50 metre width with four spans. While its piers were constructed with stone, the superstructures were passed by timber beam structure, which was covered by soil covering. This bridge was restored by the General Directorate of Highways between 2010 and 2012 [12].

The third example of a timber beam bridge is the historical Yakaören Bridge in Abana District in Kastamonu from late 19th century. It has 18.50 metres length and 2.80 metres width with one span of 11.52 metres. It passes the river with two wooden logs with a $40 \mathrm{~cm}$ radius assembled over the stone abutments. The timber beam structure was supported under and over by strutting timber elements as shown in Figs 18 and 19 [13].

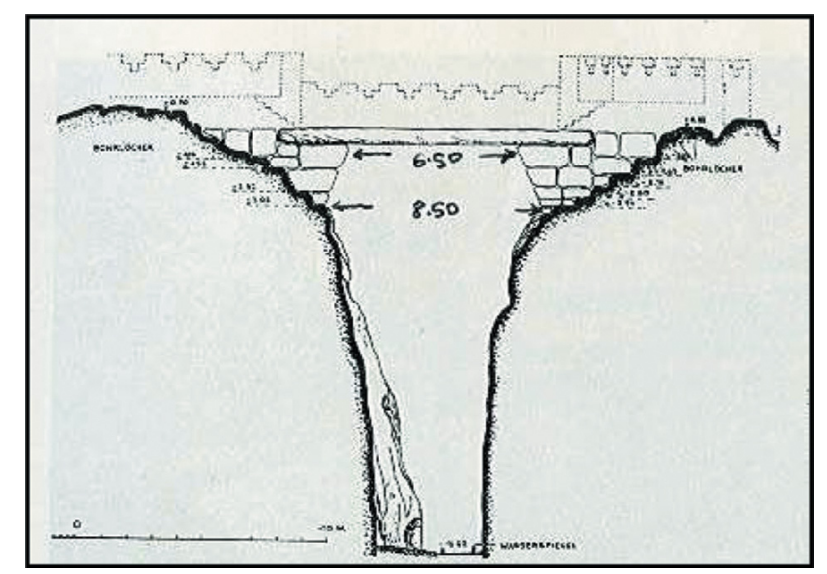

Figure 15: Reconstruction drawing of Hittite timber bridge [11]. 


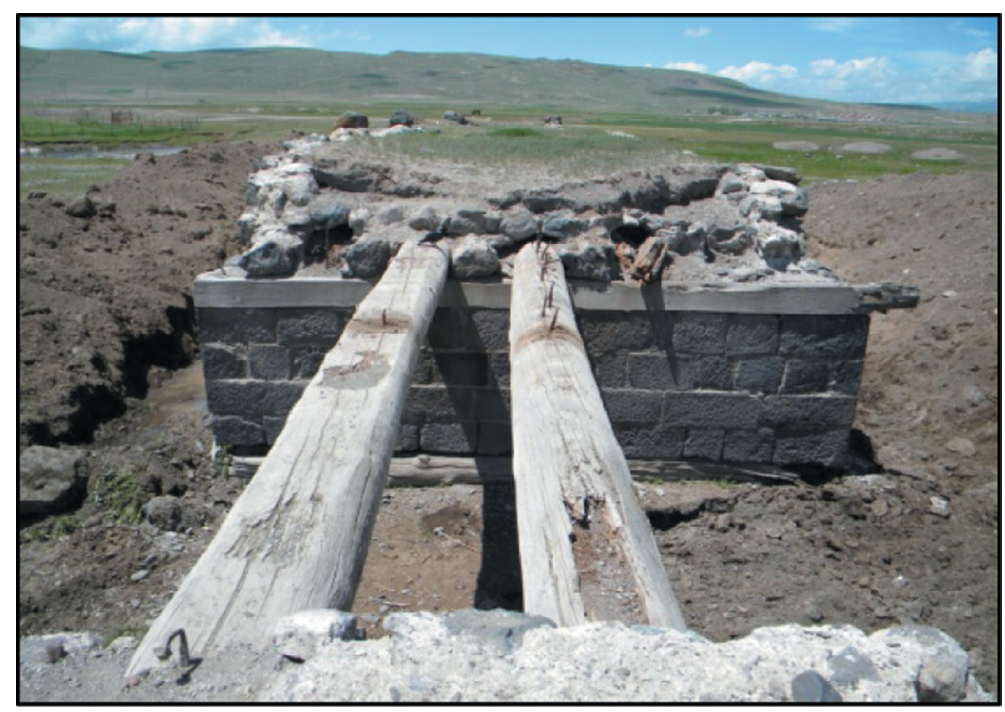

Figure 16: The view from the deck of the bridge of the historical Pulur Bridge in Erzurum [12].

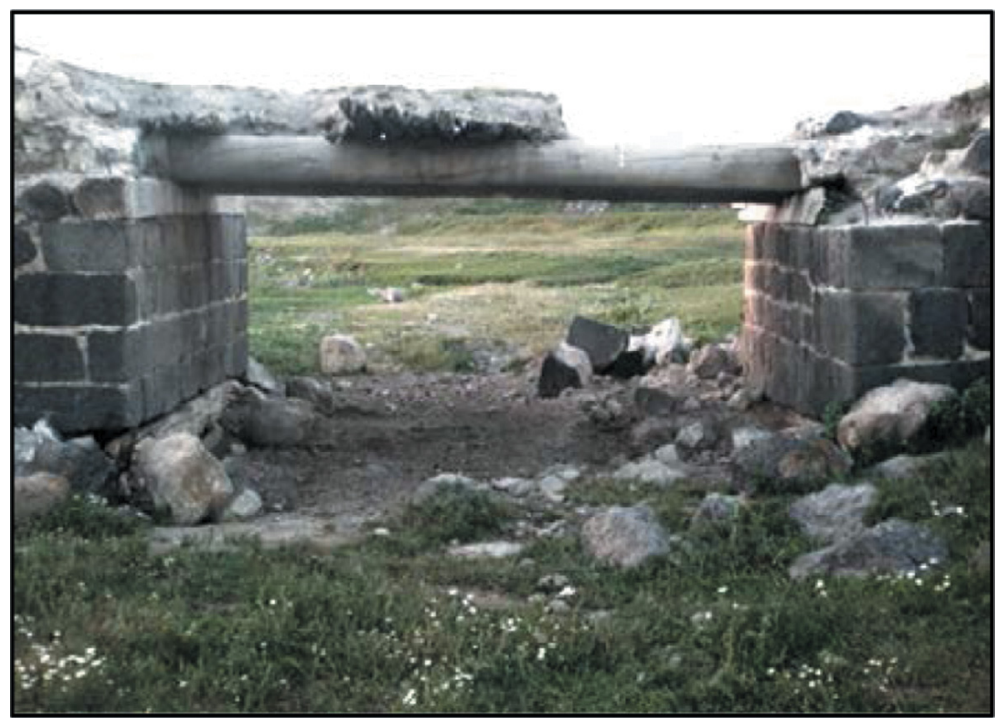

Figure 17: Side view of the historical Pulur Bridge in Erzurum [12].

\subsection{Timber cantilever bridges}

A cantilever bridge is a developed form of beam bridges to span wider distances [4]. In Turkey, timber bridges constructed with cantilevered beams are generally in hybrid forms because of the additional construction forms. Here only the examples of cantilever timber bridge from Turkey will be given.

The historical Buzlupinar Bridge on Madenli Stream in Buzlupınar Village, in Çayeli district of Rize province. The bridge was burned out during a fire in 1906 and reconstructed by 


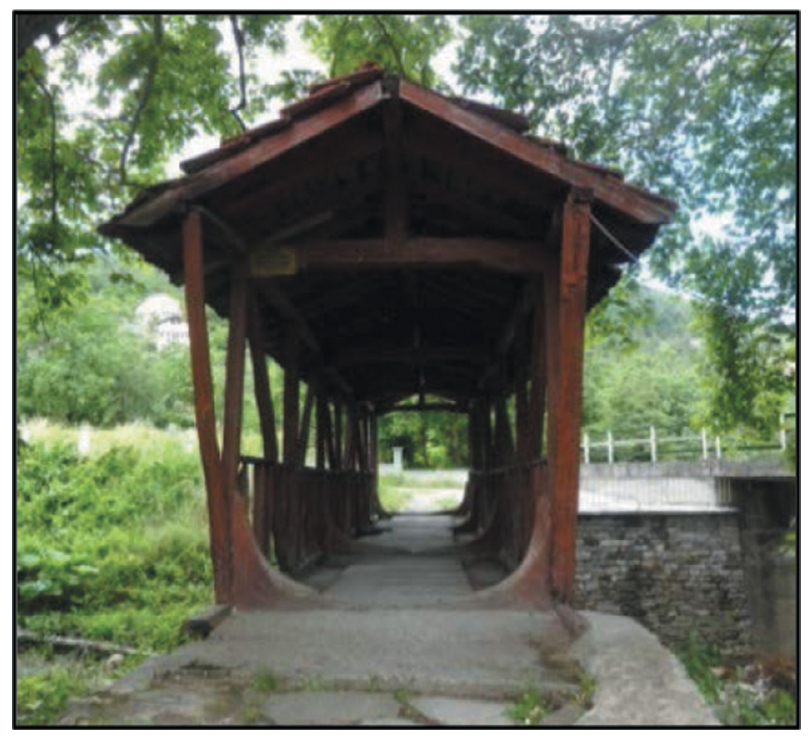

Figure 18: The upper structure of the historical Yakaören Bridge in Kastamonu (Photo credit: S. Yilmaz, June 2016).

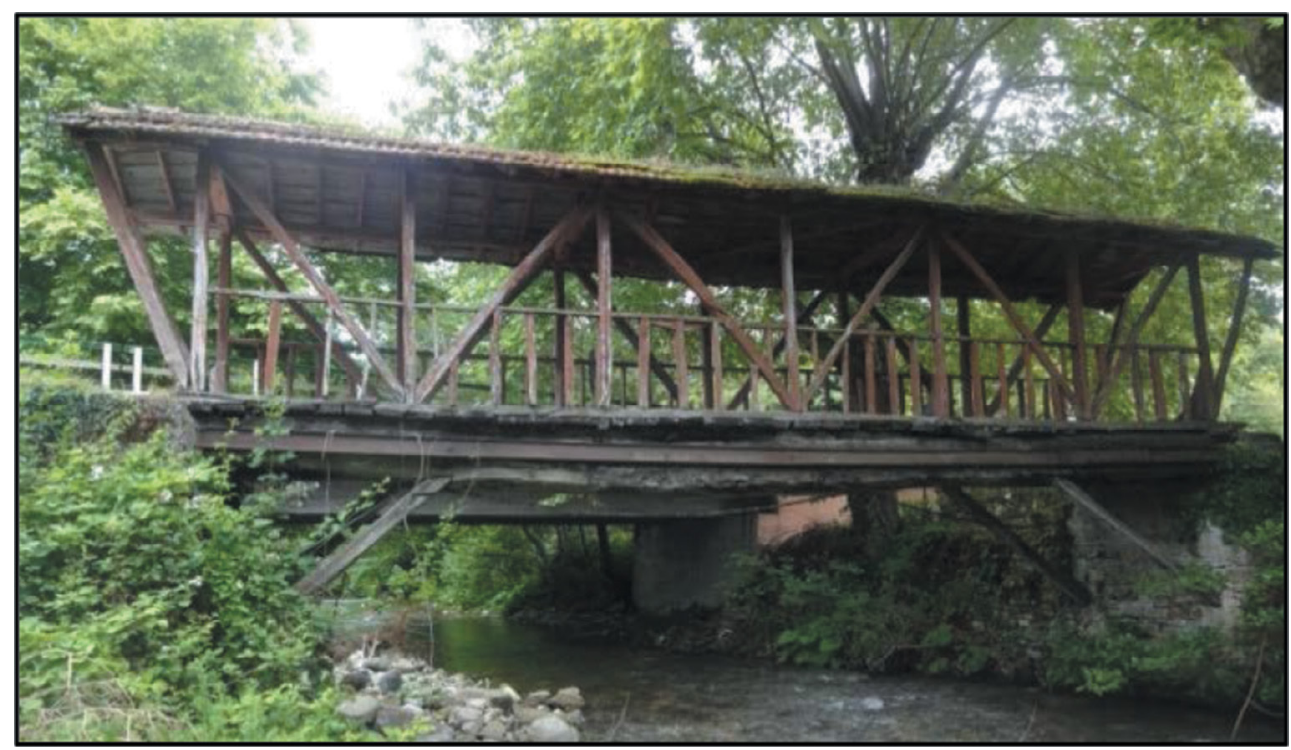

Figure 19: The side view of the historical Yakaören Bridge in Kastamonu (Photo credit: S. Yilmaz, June 2016).

the inhabitants after the fire. The bridge is approximately 35 metres in length and 2.20 metres in width and its 21.80 metres span length decreased to 12.50 metres by cantilever transverse and longitudinal beams overlapping on each other. Because the superstructure of the bridge was fallen down in 1980s, it was restored by the General Directorate of Highways between 2012 and $2016[14,10]$ (Figs 20 and 21). 


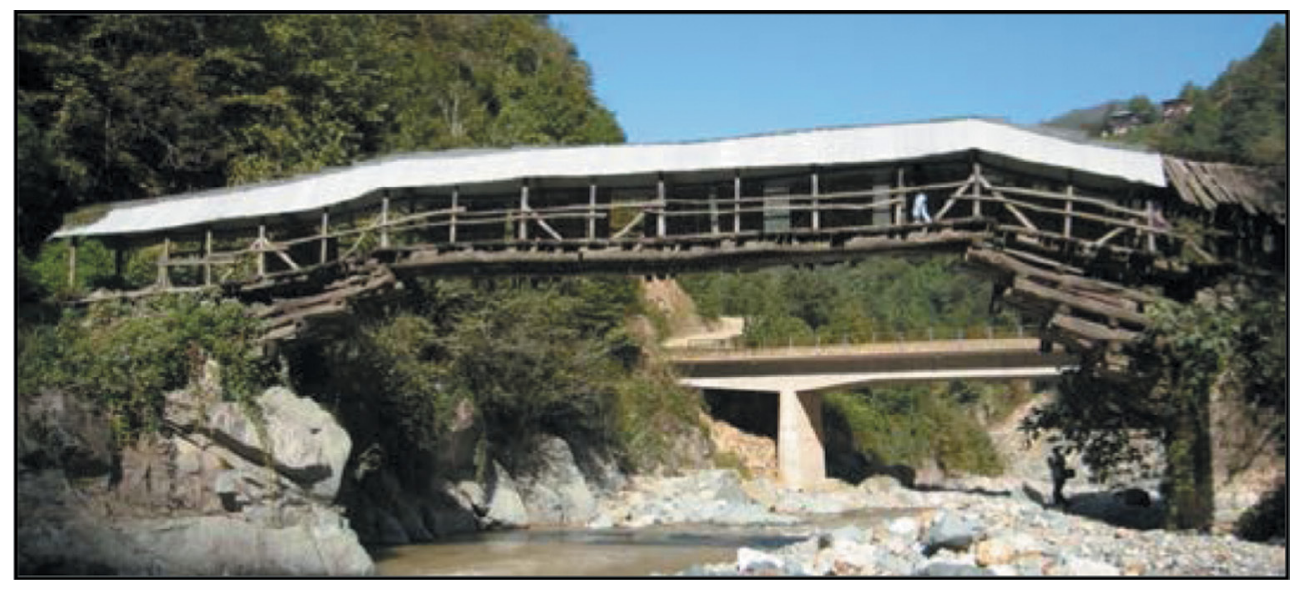

Figure 20: The side view of the historical Buzlupınar Bridge in Rize [10].

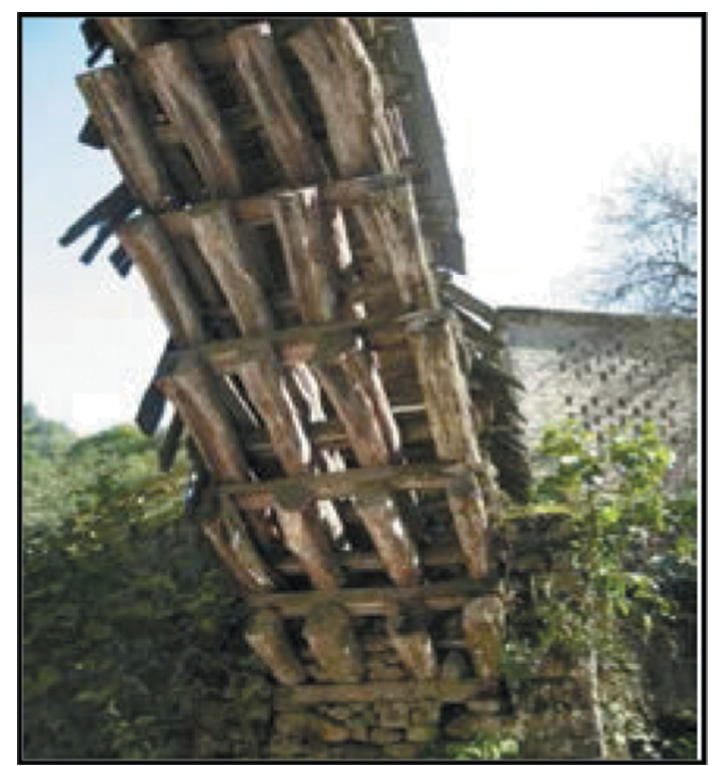

Figure 21: The view from cantilever beams of the historical Buzlupınar Bridge in Rize [10].

\subsection{Timber suspension bridges}

Basically a suspension bridge is formed with a rope hanging between the supports [4]. In Turkey, there are examples of timber suspension bridges hanging by structural timber elements.

The historical Dörtocak Köprüsü is from the 19th century in Tosya District in Kastamonu with 11.20 metres length and 3.90 metres width. One bridge was constructed over the river spanning 10 metres with five wooden beams with a radius of 35 centimetres assembled on side stone abutments. The superstructures of the bridge constructed with timber beam logs 
were hanged by timber elements. On the deck, trail woods were placed along the bridge deck for the easy access of coaches [15] (Figs 22 and 23).

\subsection{Timber hybrid bridges}

In Turkey, hybrid forms were generally used with the combination of cantilever and suspension bridges.

The first example is the historical Bayramören Bridge, located on Melan (Soğanlı) Stream in Bayramören Sub-district in Çankırı District; it was built in order to provide access between vineyards and truck gardens on the other bank of the stream and the settlement area. It has been rumoured that the bridge dates back to 150 years ago. The bridge is approximately 64.80 metres in length and 4.00 metres in width with double spanned of 12.21 metres and 17.03 metres.

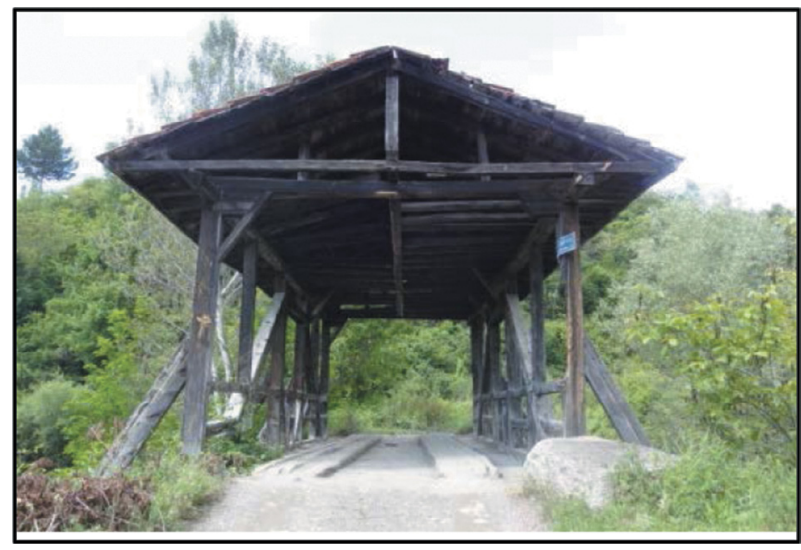

Figure 22: The upper structure of historical Dörtocak Bridge in Kastamonu (Photo credit: S. Yilmaz, June 2016).

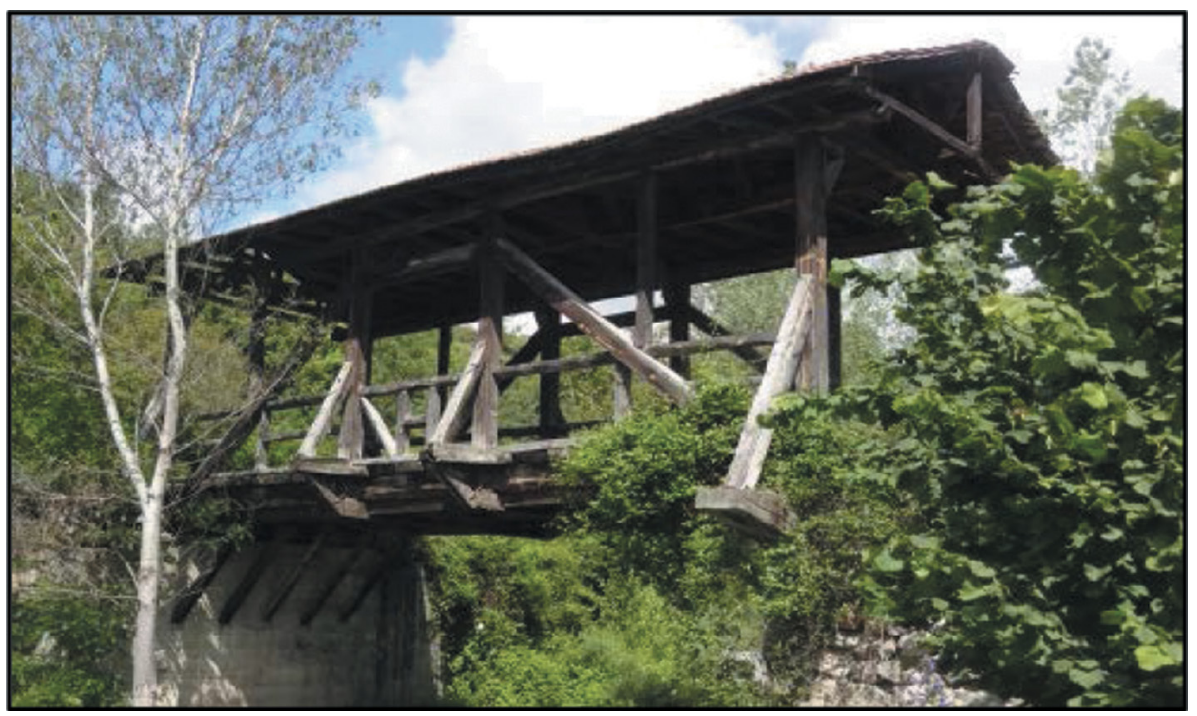

Figure 23: The side view of historical Dörtocak Bridge in Kastamonu (Photo credit: S. Yilmaz, June 2016). 
The bridge was constructed with hybrid system which combines cantilever and suspension structural systems together. That is, the main timber girders were supported by the cantilever system established through overlapping and locking transverse and longitudinal beams on the stone piers and also the main timber girders were hanged by suspension timber elements at the same time (Fig. 24).

The bridge floors were formed on the main girders at a height of 9.00 metres from the base level and trail woods were placed along the bridge floors. This bridge was reconstructed by the General Directorate of Highways between 2000 and 2001 (Figs 25 and 26) [16].

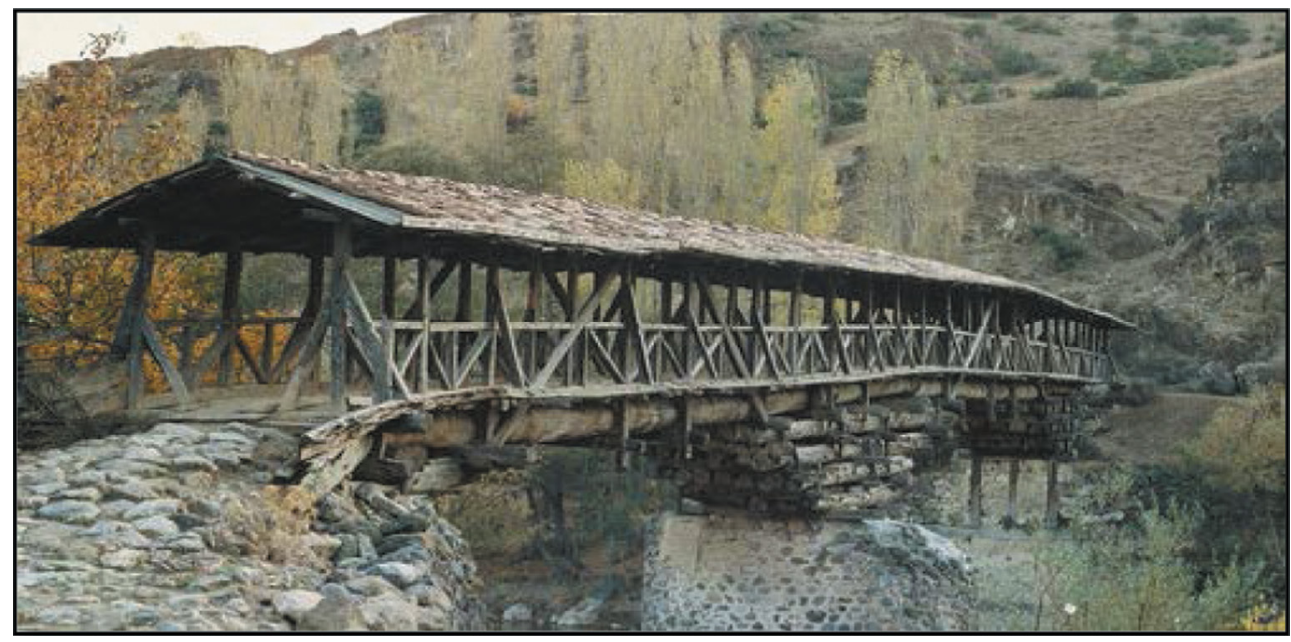

Figure 24: The historical Bayramören Bridge in Çankırı (before restoration) [16].

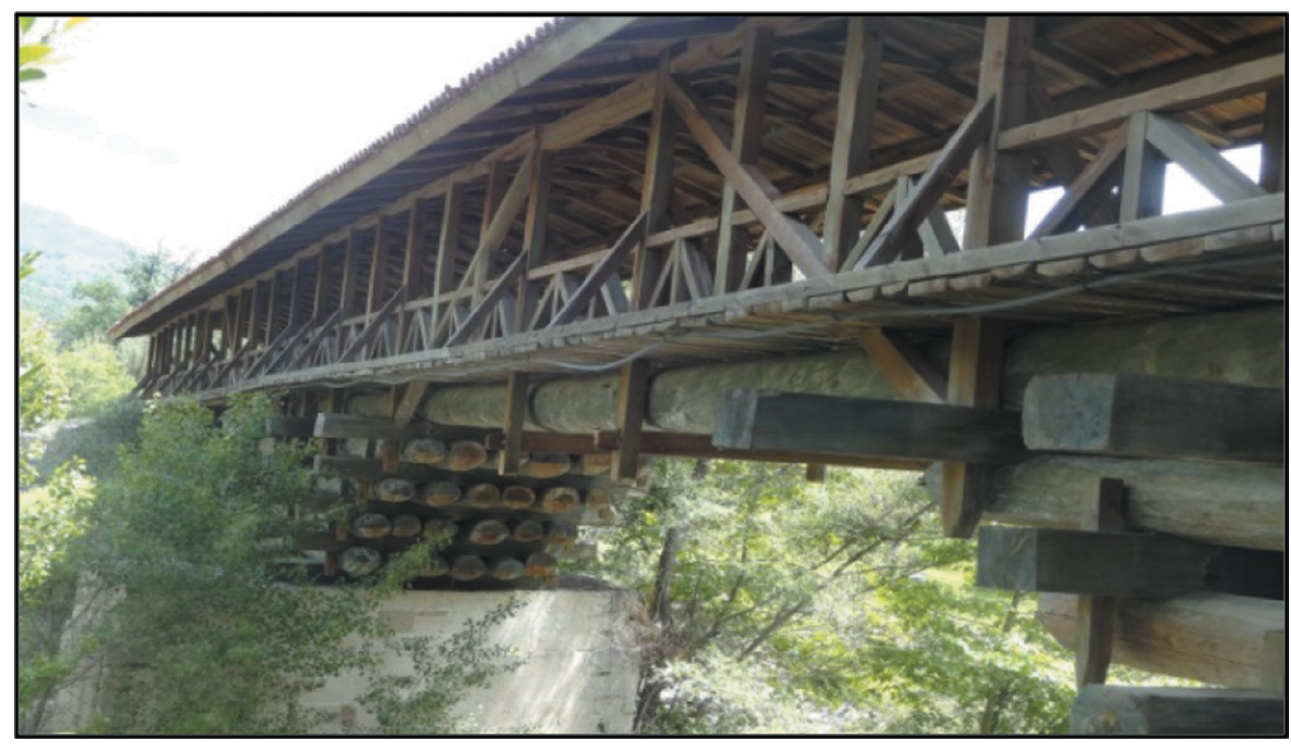

Figure 25: Side view of the historical Bayramören Bridge in Çankırı (after restoration) [16]. 


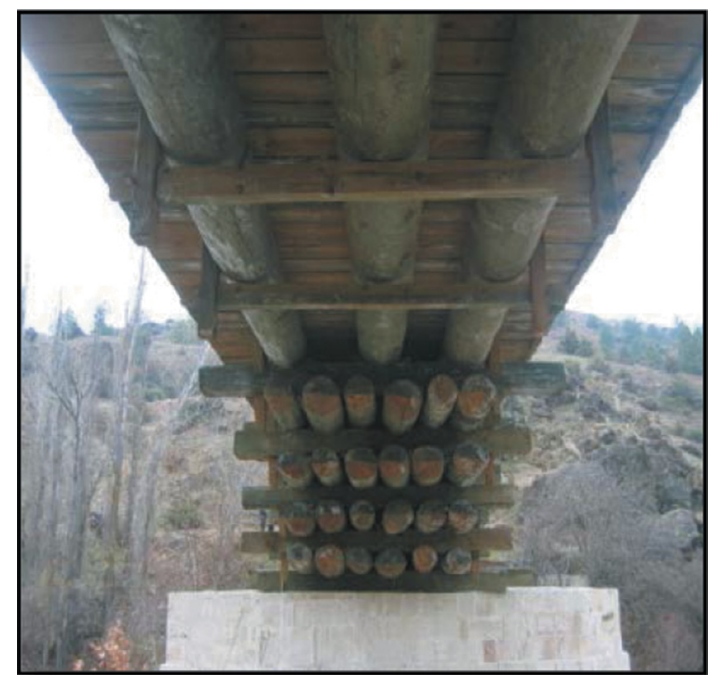

Figure 26: View from the cantilever beams and main beams of the historical Bayramören Bridge in Çankırı (after restoration) [16].

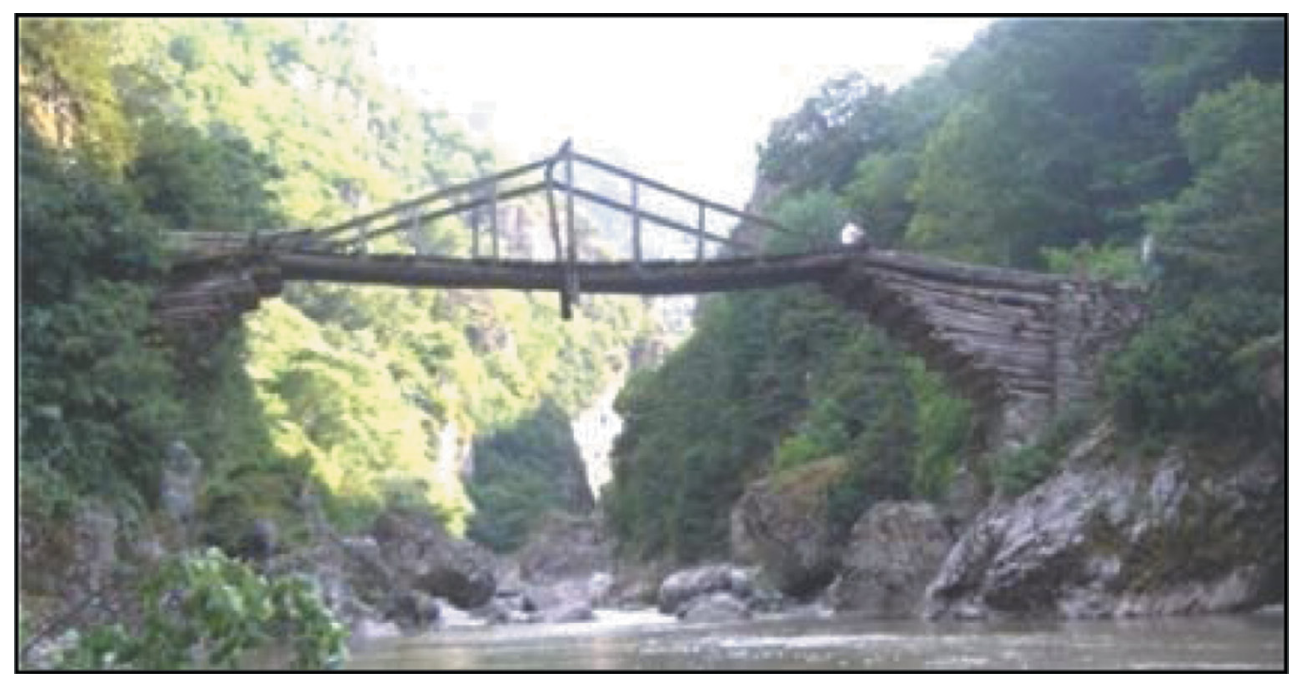

Figure 27: The historical Başkotanı Bridge in Ordu constructed with hybrid system [17].

The second example is the historical Başkotanı Bridge located in Kabadüz District in Ordu. The bridge was constructed in the 19th century with approximately 30 metres length and 2 metres width with one span of 18 metres. The bridge was constructed with hybrid system that the main timber girders were supported by the cantilever system established through overlapping and locking transverse and longitudinal beams and also the main timber girders were hanged by suspension timber elements at the same time (Fig. 27), [17]. 


\section{DISCUSSION AND CONCLUSION}

In Anatolia, historical timber bridges belonging to ancient times could not survive till now while only a few belonging to the 19th century are still standing and reflect the materials and construction technologies of the past. Those bridges, therefore, are very valuable and deserve to be discovered in terms of their technical specifications.

The present study is an effort to classify the historical timber bridges in Turkey that have survived up until today. Classification is the first step to study and understand each bridge, in order to record its preservation state as well as to document the morphology and typology of the existing bridges. By this way, the knowledge achieved in the past on timber bridge construction could be discovered for their repair and maintenance and therefore their long-term survival. The data achieved by the study are expected to be a useful and effective attempt to transfer the knowledge achieved in the past to young generations.

\section{REFERENCES}

[1] General Directorate of Highways (GDH), Inventory of the Division of Historical Bridges, Ankara, Turkey, 2016.

[2] Sert, H. et.al., Specifications, Legislation, Inventory, Projects and Maintenance - Repair of Historical Bridges, GDH Publication No: 268, GDH Printing House: Ankara, Turkey, 2009.

[3] Mettem, C. J., Timber Bridges, New York, NY: Spon Press, 2011.

[4] Brown, D. J., Bridges: Three Thousand Years of Defying Nature, MBI Publishing Company: St. Paul, MN, 2001.

[5] Setra, Technical Guide Timber Bridges How to Ensure Their Durability, Ministere de l'Ecologie du Development et de I'Amenagement Durables, 2006.

[6] Ritter, Michael A., Timber Bridges: Design, Construction, Inspection, and Maintenance, United States Department of Agriculture Forest Service, Washington, DC, 944 $\mathrm{p}, 1990$.

[7] Pašić, A., The Old Bridge (Stari most) in Mostar, Research Centre for Islamic History, Art, and Culture. Istanbul, 1995.

[8] Sert, H., Mostar Köprüsü, ICANAS 38. International Congress of Asian and North African Studies,, Atatürk Supreme Council of Culture, Language and History, Ankara, Turkey, 2007.

[9] Denison, E., \& Stewart, I., How to Read Bridges: A Crash Course in Engineering and Architecture. Rizzoli: New York, 2012.

[10] Çabuk, E., Structural Modelling, Analysis And Evaluation of the Historic Buzlupinar Bridge and Recommendations for its Reconstruction, Master Thesis, METU, Ankara, Turkey, 2015.

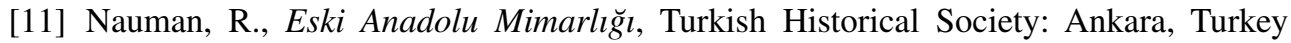
2007.

[12] General Directorate of Highways (GDH), Historical Pulur Bridge Restoration Projects and Technical Report, GDH Archive, Archieve Registration No:.12/I.25/N.86/ RUP2012, Ankara, Turkey, 2012.

[13] General Directorate of Highways (GDH), Historical Yakaören Bridge Restoration Projects and Technical Report, GDH Archive, Archive Registration No:. B.15/I.37/N.86/ RUP-2015, Ankara, Turkey, 2015. 
[14] General Directorate of Highways (GDH), Historical Buzlupınar Bridge Restoration Projects and Technical Report, GDH Archive, Archive Registration No:.B.10/i.53/N.86/ RUP-2012, Ankara, Turkey, 2012.

[15] General Directorate of Highways (GDH), Historical Dörtocak Bridge Restoration Projects and Technical Report, GDH Archive, Archive Registration No.. B.15/I.37/N.85/ RUP-2015, Ankara, Turkey, 2015.

[16] General Directorate of Highways (GDH), Historical Bayramören Bridge Restoration Projects and Technical Report, GDH Archive, Archive Registration No:B.15/I.37/N.85/ RUP-2015, Ankara, Turkey, 2015.

[17] General Directorate of Highways (GDH), Historical Başkotanı Bridge Restoration Projects and Technical Report, GDH Archive, Archive Registration No: B.10/I..55/N.25/ RUP-2016, Ankara, Turkey, 2016. 